Available Online at ESci Journals

International Journal of Educational Studies

ISSN: 2312-458X (Online), 2312-4598 (Print)

http://www.escijournals.net/IJES

\title{
EFFECTS OF COOPERATIVE E-LEARNING APPROACH ON STUDENTS ATTITUDE TOWARDS CHEMISTRY IN KOIBATEK SUB-COUNTY, KENYA
}

\author{
Chebii Roselyn, Samuel W. Wachanga, Zepheniah O. Anditi \\ Department of Curriculum Instruction and Educational Management, Egerton University, Kenya.
}

\section{A B S T R A C T}

The study investigated the effectiveness of Co-operative E-learning approach (CELA) on students' attitude towards Chemistry. The Solomon Four Group, Non-equivalent Control Group Design was employed in the study. The study was carried out in Koibatek sub-county, Kenya where there has been a persistent low achievement in the subject. 489 form three students from twelve county schools, purposively selected from the sub-county were taught the same course content on the mole for a period of five weeks. The experiment groups received their instructions through the use of CELA approach and control groups using the conventional teaching method. The researcher trained the teachers in the experimental groups on the technique of CELA before treatment. Student Attitude Questionnaire (SAQ) was used for data collection. The results of the study indicated that students in experimental groups outperformed those in the control groups. Also, there were no statistically significant differences in the mean score in SAQ between boys and girls exposed to CELA. Girls and boys performed equally well in altitudes towards Chemistry. Chemistry teachers should be encouraged to incorporate CELA method.

Keywords: Cooperative E-learning Approach (CELA), Attitudes towards Chemistry, Conventional Teaching Method.

\section{INTRODUCTION}

One of the objectives of science education is to develop students' interest in science and technology as today's society depends largely on development in science and technology. Emphasis is also placed in the application of science and technology education to the needs of daily life and development of society (UNESCO, 1997). Teachers are expected to devise ways of making their students to develop positive attitudes towards science and science related disciplines (Sola \& Ojo, 2007). Researchers focused on gender studies have indicated that attitude towards science education differs between males and females. A declining interest in Chemistry and the under representation of females in chemical science was found (Banya, 2004). Self-confidence toward Chemistry, the influence of role models and knowledge about the usefulness of Chemistry affected the decision of young female students about the study of Chemistry. Attitudes are acquired through learning and can be changed by

\section{* Corresponding Author:}

Email: roselynchb@gmail.com

(C) 2018 ESci Journals Publishing. All rights reserved. using a variety of techniques. Attitudes once established help to shape the experiences. People constantly form new attitudes and modify old ones when they are exposed to new information and new experiences (Adesina \& Akinbobola, 2005). According to Yara (2009), attitudes of students can be influenced by the attitude of the teacher and his methods of teaching. He further showed in his work that teachers' method of mathematics teaching and his personality greatly accounted for students' positive attitude towards the subjects and that without interest and personal effort in learning by the students can hardly perform well in the subject.

Gilbert (2006), listed several problems that are believed to have the potential to affect attitude towards an interest in learning Chemistry. These are issues such as overload of the subject matter, failure to present a holistic approach to Chemistry (i.e. presentation of isolated facts). Inadequate emphasis regarding selection and depth of the topics taught especially for those are not going to embark on a career in Chemistry or Chemistry related sciences. He finally suggested that many programs suffer from a lack of relevance. 
CELA is an acronym got by integrating existing cooperative learning and E-learning approach. It was an approach used in teaching the experimental group in this study to see whether it improved learners' attitude towards Chemistry. This method of teaching had not been tried out in Chemistry teaching and learning in Koibatek sub-county, Kenya where performance in the subject had continued to decline.

\section{RESEARCH HYPOTHESIS}

The purpose of the study was to determine the effects of Cooperative E-learning Approach (CELA) on students' attitude towards Chemistry.

The following null hypothesis was tested in this study at the significant level of 0.05 .

Ho1: There are no statistically significant differences in the attitudes towards Chemistry between the boys and girls who are exposed to CELA.

\section{METHODOLOGY}

Research Design: The study used Solomon Four Nonequivalent Control Group Design. This is because there was a non-random selection of students to the groups. Secondary school classes exist as intact groups and school authorities do not normally allow the classes to be dismantled and constitute for research purposes (Fraenkel \& Wallen, 2009).

Four groups of participants, the Experimental Group One (E1). Experimental Group Two (E2), Control Group One $\left(\mathrm{C}_{1}\right)$ and Control Group Two $\left(\mathrm{C}_{2}\right)$ was used. Groups $\mathrm{E}_{1}$ and $\mathrm{E}_{2}$ formed the experimental groups which received treatment (CELA) while $\mathrm{C}_{1}$ and $\mathrm{C}_{2}$ were the Control Group that did not receive treatment. Groups $\mathrm{E}_{1}$ and $\mathrm{C}_{1}$ received pre-test while $\mathrm{E}_{2}$ and $\mathrm{C}_{2}$ did not. All groups received the post-test at the end of the course. To avoid the interaction of students from different groups that may contaminate the results of the study; one class from a school constituted one group of students, hence four groups were required for this study.

Sample: The actual sample size that participated was 489 form three students, selected using purposive sampling method. Table 1 shows the sample size.

Table 1. Sample Size of the study.

\begin{tabular}{cc}
\hline Group & Number of students \\
\hline $\mathrm{E}_{1}$ & 141 \\
$\mathrm{E}_{2}$ & 123 \\
$\mathrm{C}_{1}$ & 120 \\
$\mathrm{C}_{2}$ & 105 \\
\hline Total & 489 \\
\hline
\end{tabular}

Development and Use of Teaching Materials: The content used in the class instruction was developed and based on the revised KIE, 2002 Chemistry syllabus teachers guide, students' textbook and other relevant materials. Teachers module included the content to be covered, lesson plan to be used in teaching the topic mole in form three Chemistry and the use of computers. Student manual was the CELA modules which introduce the learners to the use of computers in learnings topic mole in Chemistry. The teachers in the experimental groups were trained by the researcher on the use of the module and cooperative learning for one week to the commencement of the treatment. They were given the modules by the researcher. In the control groups, the conventional teaching/learning methods were used. Classes in all the four groups used the same curriculum materials and spent five weeks on the topic mole as recommended in the syllabus.

Instrumentation: The instrument used to collect the data was Student Attitude Questionnaire (SAQ).

Student Attitude Questionnaire (SAQ)

The Student Attitude Questionnaire (SAQ) was adapted from Rockwood, Sangster, and Dillman (1997), Abulude (2009) and modified to suit the study. Each item in the questionnaire was developed to address research hypotheses of the study. The maximum score for each item was 5 . The items were close ended and based on the five points Likert Scale; Strongly Agree SA (5); Agree - A (4); Undecided U (3); Disagree - D (2); Strongly Disagree - SD (1).

Data Collection Procedure: The students in the study were randomly assigned into the four groups experimental group $1\left(\mathrm{E}_{1}\right)$, experimental group $2\left(\mathrm{E}_{2}\right)$, control group $1\left(\mathrm{C}_{1}\right)$ and Control group $2\left(\mathrm{C}_{2}\right)$. A pre-test was conducted in the experimental group $\left(E_{1}\right)$ and control group $\left(\mathrm{C}_{1}\right)$ in order to measure the student entry behaviour before the treatment. In the experimental group, $E_{1}$ and $E_{2}$ CELA was used while in control groups $\mathrm{C}_{1}$ and $\mathrm{C}_{2}$ conventional teaching method was used. At the end of the treatment period, the post test (SAQ) was administered to all the groups. The researcher supervised the teaching and scored the pre-test and post-test results.

Data Analysis: To test for differences between two means, t-test and ANCOVA was used. The hypothesis was tested at the $\alpha=0.05$ level of significance.

RESULTS

The pre-test was administered to groups $\mathrm{E}_{1}$ and $\mathrm{C}_{1}$ to 
determine the student's entry behaviour before teaching started.

Table 2 shows the independent sample t-test of the pretest scores on SAQ.

Effects of CELA on Attitudes towards Chemistry of Boys and Girls who were exposed to it: The objective of the study sought to find out whether students' attitude towards Chemistry was gender dependent when
CELA was used. The corresponding hypothesis stated that there was no statistically significant difference in the attitude towards Chemistry between boys and girls who were exposed to CELA. An independent t-test was carried out as shown in Table 3.

ANCOVA was carried out in order to account for any initial difference that could have existed between the boys and girls as shown in Table 5 .

Table 2. The Independent Samples t-test of the pre-test Mean Score on SAQ.

\begin{tabular}{cccccccc}
\hline TEST & GROUP & $\mathrm{N}$ & MEAN & SD & df & t-value & P-Value \\
\hline SAQ & $\mathrm{E}_{1}$ & 141 & 13.35 & 0.50 & 255 & 0.55 & 0.58 \\
& $\mathrm{C}_{1}$ & 116 & 12.93 & 0.54 & & &
\end{tabular}

The results of Table 2 revealed that the difference in students' scores in SAQ were not statistically significant at $t$ $(258)=0.55, p>0.05$. The groups used in the study exhibited comparable characteristics and therefore suitable for the study.

Table 3. The difference in Attitude towards Chemistry by Gender of Students Exposed to CELA.

\begin{tabular}{cccccccc}
\hline GROUP & GENDER & $\mathrm{N}$ & MEAN & SD & DF & t-value & p-value \\
\hline Experimental & Male & 114 & 3.79 & 0.55 & 252 & 1.89 & 0.06 \\
& Female & 140 & 3.92 & 0.49 & & & \\
\hline
\end{tabular}

Table 3 shows that there were no statistically significant differences in the mean scores in the SAQ between boys and girls exposed to CELA; $\mathrm{t}(252)=1.89 ; \mathrm{p}>0.05$. Table 4 shows the adjusted student attitudes towards Chemistry mean score with KCPE as a covariant.

Table 4. Adjusted Student Attitude towards Chemistry Mean Scores by Gender with KCPE as a Covariant.

\begin{tabular}{cccc}
\hline Gender & $\mathrm{N}$ & Mean & Standard error \\
\hline Male & 114 & 3.81 & 0.05 \\
Female & 140 & 3.91 & 0.05 \\
\hline
\end{tabular}

Table 5. ANCOVA Students Attitude towards Chemistry Comparison by Gender.

\begin{tabular}{cccccc}
\hline SOURCE & SUM OF SQUARES & DF & MEAN SQUARE & F-ratio & p-value \\
\hline KCPE & 0.09 & 1 & 0.09 & 0.34 & 0.56 \\
& 0.52 & 1 & 0.52 & 1.94 & 0.17 \\
\hline TOTAL & 3856.978 & 254 & & & \\
\hline
\end{tabular}

From table $5(\mathrm{~F} 1,251)=1.94 \mathrm{p}>0.05$.

It indicates that there was no statistically significant differences in attitude towards Chemistry between boys and girls exposed to CELA.

Hypothesis Ho1 was accepted implying that the boys and girls who were exposed to CELA performed equally well. Gender had no effect on attitude towards Chemistry of students.

\section{DISCUSSIONS}

In this study the researcher found that there was no statistically significant difference in the mean scores of
SAQ when t-test and analysis of variance ANCOVA was done, $p$ values was greater than $0.05 p>0.05$. The boys and girls exposed to CELA performed equally well. Gender has no effect. These observations are in agreement with the findings of similar studies carried out earlier. Gardunio (2001) investigated gender differences in cooperative problem-solving on students. She found no statistically significant difference in attitudes towards the subject matter. Katz, Evans, and Francis (1995) in his research reported that there was 
no significant difference in the attitudes of males and female students when cooperative learning was used. Abubakkar and Oyuguo (2011) in their studies on the comparison of boys and girl's performance, found no statistically significant difference. Learners performed equally well. Kirkpatrick and Cuban (1998) from their studies concluded that, when females and males' students at all levels of experience on computer, male and female attitudes were similar, no statistically significant difference. The findings are in agreement with those of Salta and Tzougraki (2004), in their studies, they found no statistically significant difference between boys and girls' attitude towards Chemistry. Can (2012) did a similar study and found that boys and girls attitudes towards Chemistry was slightly average, no statistically significant difference. In conclusion, gender had no effect on attitudes towards Chemistry.

\section{CONCLUSION}

In this article, an attempt was made to use the results of the study to test whether the hypothesis was false or true. From the post-test and pre-test results, the mean score, obtained by students in groups $\mathrm{E}_{1}$ and group $\mathrm{C}_{1}$ were not statistically significant. But after treatment, the students who were exposed to CELA ( $E_{1}$ ) outscored control $\left(\mathrm{C}_{1}\right)$. Students' attitude towards Chemistry is not affected by gender when CELA was used.

\section{REFERENCES}

Abubakkar, R. B., \& Oyuguo, D. O. (2011). Age and Gender as Creditors of Academy Achievement of College Mathematics and Science Students. International Conference on Teaching and Learning and Change.

Abulude, F. 0. (2009). Students attitudes towards chemistry in some selected secondary schools in Akure South. In. Akure, Nigeria: Science and Education Development Institute.

Adesina, A. O., \& Akinbobola, A. O. (2005). The attitude of students towards part-time degree programme of the faculty of education, Obafemi Awolowo University, Ile-Ife. Journal of Research of Education, 2(1), 1-4.

Banya, S. (2004). Study of factors affecting attitudes of young female students toward chemistry at the high school level. (PhD), University of Southern Mississippi, Hattiesburg, Mississippi.

Can, H. B. (2012). Students' attitudes toward school chemistry: The effect of interaction between gender and grade level. Paper presented at the
Asia-Pacific Forum on Science Learning and Teaching.

Fraenkel, R. J., \& Wallen, E. N. (2009). How to design and evaluate research in education. (4th ed.). San Francisco: McGraw-Hills.

Gardunio, E. L. H. (2001). The influence of cooperative problem solving on gender differences in achievement, self-efficacy, and attitudes toward mathematics in gifted students. Gifted Child Quarterly, 45(4), 268-282.

Gilbert, J. K. (2006). On the Nature of "Context" in Chemical Education. International Journal of Science Education, 28(9), 957-976. doi:10.1080/09500690600702470

Katz, Y. J., Evans, T., \& Francis, L. J. (1995). The Reliability and Validity of the Hebrew Version of the Bath County Computer Attitude Scale. Journal of Educational Computing Research, 13(3), 237244. doi:10.2190/13vm-flm5-4p9x-kkg1

Kirkpatrick, H., \& Cuban, L. (1998). Should we be worried? What the research says about gender differences in access, use, attitudes, and achievement with computers. Educational technology, 38(4), 56-61.

Rockwood, T. H., Sangster, R. L., \& Dillman, D. A. (1997). The Effect of Response Categories on Questionnaire Answers. Sociological Methods \& Research, 26(1), 118-140. doi:10.1177/0049124197026001004

Salta, K., \& Tzougraki, C. (2004). Attitudes toward chemistry among 11th grade students in high schools in Greece. Science Education, 88(4), 535547. doi:10.1002/sce.10134

Sola, A. O., \& Ojo, O. E. (2007). Effects of project, inquiry and lecture-demonstration teaching methods on senior secondary students achievement in separation of mixtures practical test. Educational Research and Reviews, 2(6), 124-132.

UNESCO. (1997). 50 years for education documentation. In. Paris, France: Information Services, Education Sector.

Yara, P. O. (2009). Students attitude towards mathematics and academic achievement in some selected secondary schools in Southwestern Nigeria. European Journal of Scientific Research, 36(3), 336-341. 